Online: http://journal.uny.ac.id/index.php/jppfa

\title{
DEVELOPING THE QUALITY OF EARLY CHILDHOOD MENTORING INSTITUTIONS
}

\author{
Sri Hartini \\ Universitas Ahmad Dahlan \\ hartini_sri08@yahoo.co.id
}

\begin{abstract}
The study was to uncover the concept of quality improvement, the supporting and the inhibiting factors within the quality improve and the quality improvement in the early childhood mentoring institutions/kindergarten. The study was a qualitative research. The subjects in the study were kindergarten principals, kindergarten teachers and parents. The data were gathered by means of observation, interview and documentation. For the data analysis, the researcher selected the qualitative descriptive data analysis method. The results of the study were as follows. First, the concept of educational quality improvement in the early childhood mentoring institutions/ kindergarten has been improveed from the vision, the mission and the objectives and the concept includes the aspects of planning, process and output which has synergy from one to another. The planning has been formulated in the curriculum, the syllabus and the daily activity plan. Second, the approach, the strategy and the technique of quality improvement has maximized the wellqualified schools' resources, have been supported by the sufficient facilities and have been funded by the sufficient budget. Third, the supporting factors within the quality improvement of early childhood mentoring institutions/kindergarten have been the increasing awareness within the society toward the significance of early childhood mentoring institutions, the massive socialization conducted by the Office of Education through the provision of training programs in relation to the early childhood mentoring institution/kindergarten management and the human resources empowerment toward developing the quality of early childhood mentoring institutions. Fourth, the inhibiting factors within the quality improvement of early childhood mentoring institutions have been the lack of society care and participation, the less quality human resources that early childhood mentoring institutions have, the fund limitation, the facility limitation and the lack of program management effectiveness.
\end{abstract}

Keywords: development, educational quality, kindergarten 


\section{INTRODUCTION}

The quality of Indonesian human resources, by many parties, has been considered low. The reason is that the Indonesian educational quality in any educational forms and degrees has been poor (Hadis \& Nurhayati, 2010, p. 2). One of the indicators which states the low educational quality is the Indonesian Human Development Index (HDI) that has still been low over the years (Janawi, 2014, pp. 8-9; Kunandar, 2007, p. 1) . In addition, the low educational quality is also apparent in the international academic quality through the results of Program for International Student Assessment (PISA); in this program, the Indonesian students are still in the low rank (Hayat \& Yusuf, 2010). Therefore, the human resources development should be conducted altogether with the edu-cational quality improvement.

According to Aqib, Jaiyaroh, Diniati, \& Khotimah (2009, p. 16), one of factors that have caused the low educational quality is the raw input, namely the student candidates; the reason is that up to date our attention for the early childhood education have still been very minimum. This statement has also been proposed by Anwar \& Ahmad (2007, p. 12). Therefore, one of the ways to improve the human resources quality is to pursue the development on the educational quality of early childhood education (PAUD, Pendidikan Anak Usia Dini) because early childhood has been a fundamental and very important early stage of human beings' growth and development (golden ages). This stage has been considered as the sensitivity age, the criticality age and alike by the experts.

This concept is based on the facts that have been found by neurologists. According to Woolfolk (2007, p. 32), approximately one month after the fertilization has occurred the brain starts to improve. The neuron cells appear in extraordinary speed namely 50,000 to $1,000,000$ per second until the next three months. When a baby is born, he or she will have around 100-200 billion neuron cells that keep expanding and keep being connected mutually if these neuron cells are stimulated by the environment. Similar statement has also been proposed by Berk \& Meyers (2015, p. 121), who suggests that the complexity in this neuron connection will determine the child's intelligence level. The interneuron connections (synapses) that are not frequently used will be dead, while the ones that are frequently used will be stronger and more permanent. Therefore, there should be appropriate stimulates from the environment.

The early childhood education recently has been gaining more serious attention. Even in Indonesia, the early childhood education, which is also known as PAUD, has become one of the priorities in the national education development. This matter is not apart from the findings with regards to the growth and development of the child's brain. According to Putra \& Dwilestari (2012, p. 1), the advanced studies regarding the brain have provided more accurate, richer and deeper information toward the development of human brain appropriately since the inception; through the benefits of advanced technologies, people nowadays might differentiate between the results of advanced brain study and those of the old one.

Gordon \& Browne (2011, p. 5) defines early-age child (AUD, Anak Usia Dini) as the child whose age is between zero and six or seven years old (first grade). According to Morrison (2007, p. 4), early childhood refers to the children whose age is between several months old and eight years old. According to Law Number 20 Year 2003 regarding the National Education System, the early child refers to the child whose age is between zero and six years old (Presiden Republik Indonesia, 2003). Sulistyo (2011, p. 12) defines that a child might be regarded as belonging to the early childhood if his or her age is between zero and twelve years old.

Significant. The early childhood education (0-6 years old) is significant since it has been regarded as the golden age, the sensitivity age, the opportunity window and alike by the experts. This age is marked by the developing number and function of the child's neuron cells. The functionality of these neuron cells will run optimally if there are synergized efforts. According to Asmani (2011, p. 39), during the golden ages there is extraordinary change in the children's physic and brain but in the same time they become vulnerable. Thereby, this age has been a very important age for the children's intellectual, emotional and social development in the future. 


\section{Early Age Children Development}

Human beings keep developing and keep changing during the course of their life physically, mentally and spiritually from their concept, birth, childhood, youth, adulthood, maturity and death. The changes occur in all aspects and influence these aspects from one to another. These changes are influenced by the learning process or the experience. In relation to the problems of the early age child development, the researcher would like to discuss the following matters respectively: (a) the definition of development; (b) the principles of development; and (c) the aspects of development along with their influence factors.

The definition of development. There are many opinions regarding the development that have been proposed by the experts. Woolfolk (2007, p. 22) states that development has only been a change that appears with certain sequence and is permanent. Then, Santrock (2010, p. 29) defines that development has been a pattern of biological, cognitive and socio-emotional change that starts from the period of conception and that spans during the life course. In brief, both opinions are similar yet they have different emphasis. Furthermore, Salkind $(2004$, p. 5) defines the development as a sequence of progressive changes that occurs within a predictable pattern as a result of interaction between biological and mental influences; however, the core of this opinion is that development brings about changes. The strength of Salkind's opinion is that changes are progressive and, therefore, it is similar to the two definitions that have been proposed previously and it is also similar to the opinion that has been proposed by (Yusuf LN. (2011, p. 15) who states that development has been systematic, progressive and continuous changes within an individual from the birth until the death of the individual.

Slavin $(2014$, p. 30) states that the term development refers to how people improve, adjust and change themselves during the course of their life. This development might entail the physical development, the personality development, the sosio-emotional development, the cognitive development and the linguistic development. This opinion certainly obscures the meaning of growth and of development because both of these terms (physical and non-physical change) is referred to as development. This means that according to Slavin development entails physical and pychological aspects.

Based on the opinions that have been mentioned above, the researcher might state that growth and development are two inseparable aspects that might not stand alone from one to another. Both of these aspects mutually influence one another. Thereby, the researcher might conclude that development is a process of biological, cognitive and socioemotional change that occurs to individuals progressively, systematically, permanently and continuously from the period of conception until the period of death influenced by innate and environmental factors.

Aspects of Early Childhood Development. According to (Slavin, 2014), teachers should understand how students think and view the world. According to Woolfolk (2007, p. 2), human beings development includes several different aspects namely: physical development, personal development, social development and cognitive development. Similar, Yusuf LN. (2011, p. 101) identifies eight aspects of development namely: physical, intelligent, emotional, language, social, personal, moral and religious awareness development.

Physical development. Physical development is a change that occurs in the human beings' physical organs that became the fundamental capacity in performing the skills of bodily movement. In relation to the theory of multiple intelligence, these skills of bodily movement belongs to the kinesthetic intelligence namely the skills of solving problems by using some parts or all parts of an individual's body; for example, dancers, athletes and people with bodily movementrelated professions display the kinesthetic intelligence (Gardner, 2003, p. 24). Physical development that will be discussed in the study is the one that has been related to the change of the brain and the body because the kinesthetic skills are the results of coordination between both organs.

The brain development of early child occurs very rapidly altogether with the development of other nervous system. Early childhood education, therefore, has a very important role in providing stimuli in order that the brain development might occur optimally. 
Rushton (2010, p. 92) states that the learning principles should be adjusted to the brain development that occurs uniquely in an organized manner. The child's brain should be provided with stimuli in the form of actual life and experience. The more appropriate the stimuli that have been provided, the more excellent the nervous system development and the more increasing the number of the interneuron connection or the synapses.

\section{Motor Development}

After the early-age children have achieved their physical development, they will achieve the motor skills development which refers to the control of physical movement development through the coordinated activities in the nerve center, the neuron cells and the muscles. The motor skills are usually categorized into two types namely gross motor skills and fine motor skills. According to Papalia, Olds, Feldman, \& Gross (2001, p. 242), gross motor skills refer to the physical skills that involve the use of big muscles such as running, jumping, walking and throwing whereas fine motor skills refer to the physical skills that involve the use of small muscles and the coordination between eyes and hands.

\section{Factors that Influence the Physical-Motor Development}

Similar to the other aspects of development, the physical development is influenced by maturity and environment. The maturity or the internal factors are namely the muscle maturity, the neuron maturity and alike. Then, the environment factors are namely training or learning activities. According to Uauy \& Dangour $(2006$, p. 24), the optimization of brain development in the early life is started before the conception and this includes the nutritional suitability that supports the fetal development. Venetsanou \& Kambas (2010, p. 234) studied the influence of the environment toward the motor development of the preschool children. The results of their study show that there several factors in the environment that influence the preschool children development. One of the factors is the family where the children have been raised; family holds a very important role. Then, the factors that belong to the family are the family's economic background, the parents' educational background and the presence or the absence of siblings; all of these factors influence the children's development.

\section{Cognitive Development}

Patmonodewo (2003, p. 27) states that cognitive is often defined as intelligence or reasoning. Cognitive is a wide definition regarding the process of reasoning or observing and, therefore, cognitive refers to the behaviors that result in people attaining knowledge or anything necessary for implementing the knowledge that they have attained. The cognitive development shows the development of the children's reasoning process. The children's capacity to coordinate their reasoning process in solving multiple problems might be used as a benchmark of their intelligence development. According to Gardner (2003, p. $23)$, cognitive is defined by means of logicsmathematics intelligence namely the intelligence that is related to the logics, the number reasoning and the critical thinking.

\section{Language Development of Early-age children}

Santrock (2010, p. 60) defines language as one of the communication medium in the form of utterances, writing or marks that have been based on the system of symbol. Language consists of words and regulations to vary or to combine these words. According to Carter, Chard, \& Pool (2009, p. 519), language and literacy skills have been the essential element for the early-age children development and these skills enable them to have meaningful interaction with other people and to improve their knowledge in any domain. This statement is also supported by Werner \& Smith (2001), who state that literacy skills have been found as the strongest predictor in determining the academic success. Thereby, the research might state that the language development within the children should be optimized since their early age.

The children's capacity to master language has been a wonderful success, especially the children's accuracy in applying the syntaxes or the grammatical rules. These grammatical rules are very complex yet the children have been able to master them (Crain, 2003, p. 348). Woolfolk (2007, p. 51) state that every child in each culture masters their 
native language which is complex except at the time when they have intervening physical problems or deprivations. In order to perform effective communication within the conversation, the children at least should be able to coordinate voice, meaning, words, word sequences, tones and inflections (tone changes).

According to McDevitt \& Ormrod (2010, p. 314), in order to use the language effectively children should understand four language rules namely the rules of phonology, of semantics, of syntaxis and of pragmatics. Santrock (2010, p. 275) adds elements of morphology into the four rules. Phonology is a science of linguistic voice. Then, morphology refers to the rules of morpheme combination. Morpheme is a sequence of smallest voices that provides meaning to what people say or heard. Next, syntaxes involves how might be used in order to establish acceptable expressions, phrases or sentences. Furthermore, semantics refers to the meaning of a word or a sentence. Last but not the least, pragmatics refers to the capacity of engaging oneself into a conversation that is in accordance to the intention or the desire of the related individual. Therefore, language mastery involves very complex capacity.

\section{Socio-Emotional Development Process}

McDevitt \& Ormrod (2010, p. 419) defines emotion as feelings, both physiological ones and psychological ones, that an individual has in responding to the personal interrelated events that have been related to his or her needs and objectives. Meanwhile, Santrock (2010, p. 306) defines emotion as feelings or affection that appears when an individual is involved into a meaningful interaction. As a result, the researcher might state that emotion refers to the feelings such as happy, sad, angry and alike that occur inside an individual due to certain reasons.

Ashiabi (2007, p. 20) mentions that children's emotion is one of the way by which the children react to situations while children's social development refers to how they feel intimate/familiar to the peers based on their relationship. This social and emotional development is heavily related to one another because the children's social interaction usually appears emotionally. The children's capacity to express and adjust emotion, to understand their peer's emotion and to regulate emotion will determine their success within the social interaction.

In the preschool age (kindergarten), emotion that improves for most of the time is the self-conscious emotions such as proud, ashamed and guilty. In this age, such emotion has been common. Such emotion is usually influenced by the response of their paresnts toward the children's behaviors. The development of these self-conscious emotions reflects the important association between the emotional development and the cognitive development (Santrock, 2010). In addition, the emotion that has already appeared within the early childhood is empathy (Berk \& Meyers, 2015). Empathy has been a general emotion and it serves as an important encour-agement for the prosocial and altruistic beha-viors, namely the actions that will benefit other people without displaying any hope for something in return.

\section{Morale Development}

All individuals are born in weak state both physically and mentally. Although they are born in weak state, individuals have latent innate capacity. This innate potential demands development through solid mentoring and maintenance especially in the early childhood (Mansur, 2009, p. 45). Morality and religiosity, in relation to this statement, has been one of the aspects in the human life that should be improveed within the early-age children development. Santrock (2010, p. 476) states that morale development includes the changes inside the mind, the feelings and the behaviors in relation to the standards of right and wrong. The moral development has two dimensions namely intrapersonal dimension and interpersonal dimension. The intrapersonal dimension refers to the dimension that regulates the activities of an individual when he or she is not involved in social interactiions, while the interpersonal dimension refers to the dimension that is related to the social interaction and the conflicts within the decision-making process.

Based on the Piaget's theory, the early-age children, especially the kindergarten ones (5-6 years old) belong to the first stage namely heteronomous morality. The children who belong to this stafe consider that rules 
might not be changed and punishment has been something that is related automatically to violation. The children cannot take any moral decisions. Therefore, the parents should be the authority upholders. This statement is in accordance to the findings of Taylor, Ogawa, \& Wilson $(2002$, p. 16) in their study toward the development of children's morale in Japan; in their study, they concluded that in providing the socially oriented responses more than $50 \%$ of the children look for the adult assistance.

\section{Morale, Religion and Value Development}

The value, moral and religion development in the early age children are more encouraged by the family, the school and the society environment. The means that the children use more among the others in developing the values, the morale and the religion is the modeling medium. What the children view, hear, listen and perceive will be considered as an example that they should follow. The different moral or behavioral values that have been displayed in the family and the society will cause confusion among the children. Along with the children's physical and mental development, the children's values, morale and religion will also improve in a linear manner. According to Mansur (2009, pp. 4550) there are several stages in the value, moral and religion development within the children namely: first, the appearance of religious spirit; and second, the religiosity development within the children.

With regards to the religiosity development within the early-age children, Rakhmat (2003, p. 66) states that there are several phases that should be gone through as follows. The first phase is the fairy tale stage. This stage is begun among the three until six-years old children. In this stage, the children contemplate the concept of God according to the level of their intellectual development. Then, the second phase is the realistic stage. This stage is begun from the early age of elementary school until the adolescence. In this stage, the children will have reflected the concepts of God based on the reality. Next, the third phase is the individual stage. In this stage, the children have high emotional sensitivity in accordance to the development of their age.

Several ways that might be taken by the parents in order to sharpen the children's spirituality intelligence is serving as a role model. The early-age children like imitating anything that they see. Since parents are the very first persons that they see in the family environment, they will tend to imitate what their parents have done. It is in this situation that parents should play their role in providing good examples in front of their children. The children's spiritual essence is reflected in their spontaneous attitude, their imagination and their unlimited creativity. Spirituality here will serve as the foundation for developing self-esteem, values, religion and moral. Spirituality will provide direction and significance of life by pronouncing utterances, by taking actions and by giving attention toward the beauty of the nature. Therefore, parents should learn from their children in terms of how to re-attain the purity, the happiness, the spontaneity and the peace with both nature and God. By maintaining the children's spirituality, parents will help them to look forward and to design their future with clear, optimistic and certain view.

\section{The Quality Improvement of Early Childhood Education/Kindergarten}

According to Crosby (1979), quality is conformance to requirement. A product will have its quality if the product is already conformed to the standards that have been governed. The quality standards include raw materials, production process and finished product (Crosby, 1979).

According to (Deming, 1982) quality is the suitability between the market demand and the customer demand. Quality is a dynamic condition that has been related to products, labors, process and tasks within an environment that meets or exceeds the customer's expectation. With the quality change, there should also be changes or development in the labor skills, production process and tasks as well as changes or development in the company's environment in order to meet and to exceed the customer's expectation (Garvin, 1988, p. 49).

Zamroni (2001, p. 2) states that the school quality improvement is a systematic process that continuously improves the teaching-learning process quality and its related factors in order that the school targets might be achieved in a more effective and efficient manner. Hadis \& Nurhayati (2010, p. 3) state 
that the factors that influence the educational quality are namely the factors of curriculum, educational policy, educational facility, information technology application and communication within educational domain especially in the teaching-learning process activity, method application, modern and advanced educational approach and strategy, appropriate educational evaluation method, sufficient educational cost, professionally handled educational management and trained, knowledgeable, experienced and professional human resources.

In terms of micro-perspective or of narrow and specific view, the dominant factors that have great influence and contribution toward the educational quality are teacher's professionalism and welfare (Hadis \& Nurhayati, 2010). Within the educational process, teachers have very important and strategic role in guiding the learning participants to their adulthood, maturity and independence; as a result, teachers are often considered as the avant-garde of education. The task of a teacher is not only to master the learning materials and to possess the technical-educative capacity but also to attain good personality and personal integrity that might be relied upon so that a teacher might be the good role model for the learning participants, the family and the society (Sagala, 2009, p. 99). The followings are the fundamental elements in terms of how Indonesian people might improve the educational quality in this country (Bull, 2010).

\section{Early Childhood Education/Kindergarten Quality}

According to Gordon \& Browne (2011, p. 5), the scope of the early-age children starts from their birth until the first year of their elementary school. Then, according to Morrison (2007, p. 4), early childhood spans from the children who have just been born until the children who have reached eight years old in terms of age. Meanwhile, according to the National Association for the Education of Young Children (NAEYC), early childhood refers to the children whose age is in between 0-8 years old (Mansur, 2009). Furthermore, Sulistyo (2011, p. 12) defines that an individual is considered as a child or to be in his or her early childhood when his or her age is between 0-12 years old. Last but not the least, According to Law Number 20 Year 2003 regarding the National Education System, the early-age children refer to the children whose age is in between 0-6 years old (Presiden Republik Indonesia, 2003).

The development of early childhood education establishment is a great investment for the family and the nation. The experts or the general public commonly have acknowledged the essentialism and the importance of the education that should be provided to the early-age children. The figures and the experts such as Pestalozzi, Froebel, Montessori, Ki Hadjar Dewantara and more are the figures who have displayed their utmost attention toward the early childhood education. Most of the early childhood education/kindergarten institutions have been established rapidly in the non-formal degree by the society; this establishment certainly shows that the society has been more aware of establishing the early childhood education.

Based on a study that had been conducted collaboratively between the People's Republic of China and the United States of America in the Province of Zhejiang, Kejian $\mathrm{Li}$ and Margaret Burchinal (2016) have found that the results of well-qualified early childhood education will assist the children in developing their linguistic, mathematical and social-cognitive capacity. The education that has been conducted in the village areas have been better than the one in the city areas; then, private education is considered to better than the public or the government education.

The characteristics of service quality are more difficult to define than those of product quality because the service quality entails several elements of an important subject (Sallis, 2002, p. 3). The causes of low or inferior product quality are not similar to those of service quality. A product that has low quality or that has been broken is influenced more by its poor materials or components, its poor product design and its inappropriate specification. On the other hand, the low service quality is influenced directly by the labor's attitudes or behaviors. The lack of politeness, the lack of discipline, indifference and the lack of training activities often become the causes of low service quality.

Based on several opinions that have been elaborated above, the researcher might 
conclude that the concept of service quality within the early childhood education should be inserted into all functions and activities that have been related to the learning process such as: learning quality, learning participants quality, achievement and learning culture, service and management quality, educational facility quality and government or institution quality. Hopefully, all of these qualities might meet the expectation of the interested parties.

\section{Quality Improvement of Early Childhood Education/Kindergarten}

According to Zamroni (2001, p. 2), the school quality improvement is a systematic and continuous process that improves the quality of teaching-learning process and of factors that have been related to this teachinglearning process. The objective of this quality improvement is that the school targets might be achieved more effectively and efficiently.

Hadis \& Nurhayati (2010, p. 3) state that the macro-perspective has many factors that influence the educational quality and these factors are namely the factors of curriculum, educational policy, educational facilities, application of information and communication technology into the educational domain especially the activities of teaching-learning process, application of advanced and modern educational methods, strategies and approaches, appropriate educational evaluation method, sufficient educational cost, professional conduct of educational management and trained, knowledgeable, experienced and professional educational human resources (Hadis \& Nurhayati, 2010).

The quality improvement of early childhood education might also be viewed from the learning participants' success in developing the potentials that they possess, both the ones that are related to the right brain capacity and the ones that are related to the left brain capacity. Parental involvement in the context of rapid environmental development is important to exert in order that the learning participants' potential development might be more maximum. What the parents should do during the rapid environmental development are as follow: exerting their role (parenting and guiding their children), establishing communication (maintaining balanced information between the school and the parents themselves), putting forward voluntary actions (providing assistance to the school), making decisions (being the part of the school's decision making process) and establishing collaboration with wider society (representing the school in cooperation with other organizations).

\section{METHOD}

This study was a qualitative research, namely an in-depth and detailed review toward a case. Yin $(2014$, p. 27) stated that case study had been an empirical inquiry that investigated phenomena in the real world in case if the limitations between the phenomena and the contexts were not strictly visible and in which the multi-sources might be benefitted.

The subjects of a qualitative study were the individuals who might be the actors of certain activities within a natural setting. All of the actors who had orientation toward the quality improvement of early childhood education in the setting of this study would, therefore, be the subjects in this study and these actors were the Principal of Kindergarten, the kindergarten teachers, the kindergarten caretakers and alike. Furthermore, in this study that concept would be mentioned interchangeably with the concept of informant and of information source. The reason was that the three concepts had similar meaning according to the researcher's point of view.

In order to achieve the in-depth understanding for this study, the researcher demanded a series of data that would be gathered by means of multiple data gathering techniques. In addition to gaining an in-depth understanding toward the problems that would be studied, the data gathering techniques would also be implemented to serve as a tool for checking the data validity. The data gathering techniques that the researcher would implement in this study were in-depth interview, observation and documentation; these techniques were complementary from one to another. The researcher should emphasize that in the main data gathering techniques within the study had been the in-depth interview and observation.

The study made use of qualitative approach; therefore, the research instrument would be divided into two parts as follows: (1) the main instrument, namely the researcher herself who would gather, analyze, synthe- 
size the data and who would draw conclusions upon/verified the phenomena that had been apparent; and (2) the supporting instrument, namely the tools that might assist the researcher (the main instrument) in drawing conclusions or in verifying the phenomena that had been studied.

The data analysis technique that the researcher implemented in this study would be the descriptive qualitative technique. The statement implied that the data that had been attained within the study would be reported as they were and would be interpreted qualitatively in order to draw conclusions under the inductive principles.

Taylor \& Bogdan (1998, p. 5) defined the "qualitative methodology" as the research procedures that generated descriptive data in the form of oral or written words that had been provided by the observable people or behaviors. This approach was directed to the individuals'background that had been holistically complete. In line with the statement, Nasution $(1988$, p. 5) stated that qualitative study essentially had been observing people within their life, having interaction with these poeple and trying to understand their language and interpretation regarding the world around them.

\section{RESULTS AND DISCUSSIONS}

The concept of quality improvement for the early childhood education/kindergarterns acknowledged that the development of educational quality in the kindergarten had been based on the vision, the missions and the objectives which included the aspects of planning, process and output. These aspects were synergized aspects that would encourage the process of educational quality improvement to run well so that the process might generate the well-qualified output that would meet the objectives.

The planning of development program for the educational quality improvement in the early childhood education/kindergarterns had been written in the curriculum and the syllabus for each school and had been implemented in accordance to the standards of development achievement level (STPP, Standar Tingkat Pencapaian Pengembangan); these standards included the annual plan design and the semester plan design and both designs would be elaborated into the weekly activities plan (RKM, Rencana Kegiatan Mingguan) and the daily activity plan (RKH, Rencana Kegiatan Harian). In addition, the school environment should be set into an environment that had been full of religious values, manners and slogans that taught habituation of and synergy with the local wisdom toward all school members.

The educational quality improvement would be considered successful in achieving the minimum standards of development achievement level based on the following indicators: educator and teaching staff sufficiency in terms of quality, quantity and status; the sufficiency of APE learning instrument, facilities and nutrition; and the provision of subsidy from the government for covering the educational costs. The educational quality improvement would run well if the development would have been assisting the children's physical and spiritual growth and development so that they would be ready to enter a more advanced life in accordance to the expectations of their parents. This statement was similar to the opinion of Zamroni (2001, p. 2) who stated that the educational quality improvement of a school had been a systematic and continuous process that improved the quality of teachinglearning process and its related factors in order that that the school targets might be achievement in a more effective and efficient manner.

The results of a study by Slot, Leseman, Verhagen, \& Mulder (2015) in Netherland showed the ratio between teachers and students as well as the size of the students in a classroom had indirectly influenced the quality of a process; however, the pre-service education that the teachers experienced provided a positive in pact within the development of emotional aspects and educational quality toward the early-age children.

\section{The Supporting and the Inhibiting Factors within the Educational Quality Improvement of Early Childhood Education/Kindergarten}

The results of this study showed that the supporting factors in the implementation of quality improvement efforts within the early childhood education were as follows: (1) increasing society awareness toward the significance of early childhood education and mas- 
sive effort that the government pursued in socializing the significance of early childhood education and in providing training programs for educators and the caretakers of early childhood education through the Office of Education in order to improve their teaching, nursing and guiding capacity; and (2) the fact that human resources empowerment had been the main key to improve the educational quality of early childhood education, in addition to the sufficient learning facilities, the supporting learning quality, the parenting and mentoring and the participative management conduct.

On the other hand, the results of this study showed as well the inhibiting factors in the implementation of quality improvement in the early childhood education were as follows: (1) the lack of parental or societal care toward the early childhood education, the low society participation in the early childhood education especially in the village areas; and (2) the poor-qualified and limited human resources, the limited fund, the lack of learning facilities and the lack of effective program management.

The early childhood education and the kindergarten pursued several efforts in order to overcome and to eliminate these inhibiting factors. The efforts that they pursued included: (1) establishing good communication with the parents both by means of direct meeting and of connecting books; (2) providing good examples in front of the learning participants; and (3) creating safe, comfortable and interesting learning environment for the children so that the children might be accustomed to the good habits and might implement these good habits into their daily life.

The standards of development achievement level for the educational quality of early childhood educations institutions and of kindergarten included the rules of early age children growth and development from fours year old until six years old. The development level that had been achieved was an actualization of the potentials in all development aspects that were expected to be experienced by the children in each of their development stage; however, this development achievement did not mean the achievement of academic capacity. The children's development stage that had been achieved was an integration of all aspects of understanding, moral and religious values, physical motor capacity, cognitive capacity, linguistic capacity, socioemotional capacity and art. In order that the children achieved the optimal development level, there should be involvement from both the parents and the adults in providing overall and integrated stimulations; such stimulations included education, parenting, health, nutrition and protection and these stimulations should be provided consistently through habituation.

Educators and Teaching Staffs conducted the service that might be directly retrived by the society members and the service included: (1) education that had been provided through teaching, guiding and training activities; (2) information center; and (3) partnership or cooperation. Each domain should be analyzed in terms of input, process, output and outcomes. In details, the SPM PAUD might be viewed as follows: (1) the use of learning programs that had been issued by the Departemen Pendidikan Nasional; (2) the possession of buildings, under minimum requirements, as a place where the learning process occured; (3) the presence of learning activity programs; and (4) the presence of teaching staffs who implemented the learning activity program under the minumum qualification.

The curriculum for the learning programs of elementary childhood education institutions and kindergarten that had been implemented referred to the national curriculum, the provincial curriculum and the local curriculum; then, the operation of this curriculum referred to the aspects of child development namely religious and moral values, physical-motor development, cognitive development, lingustic development and art development in which the curriculum would be reviewed once in a year. The scope of curriculum materials included the service in accordance to the age group, the study load and the learning group. The development competency included the aspects of development and of daily learning conduct. On the other hand, the activity conduct was guided by the educational calendar that entailed the form and the substance of the activity and the activity conduct would be socialized toward the school members and the parents.

Facilities. The sufficient facilities would heavily support the implementation of 
educational activities, parenting and protection that should be adjusted to the number of the children, the social-cultural conditions and the type of service. Then, the types of service that the early childhood education and kindergarterns provided were outdoor playing facilities, indoor playing facilities, drawing books and tape recorder. In the same time, both institutions provided the following learning facilities: blocks, puzzles, art tools, balls in multiple sizes, alphabet game tools, role game tools, sensorimotor game tools, body height measurement tools and handwash utensils. All of these facilities were in good condition and functioned normally; as a result, these facilities might be applied as the children's playground and might be operated as the learning service assisting device for the teachers.

The cost that had been planned was the investment cost and the investment cost was used for providing the facilities, developing the human resources, funding the fixed working capital, covering the operational cost in the form of educator and teaching staff payment and their associated allowance, purchasing disposable educational tools or materials and indirect educational operational cost and personal educational cost that the learning participants gathered in attending the learning rocess. The fund was gathered from the government, the parents, the society and the sponsors. The use of the fund was reported to the Foundation and the Office of Education.

According to Haji (2004, p. 114), society participation in a school development might be viewed in their involvement to bear the cost that the school demanded both the popular fundamental cost in the form of educational contribution fund (DSP, Dana Sumbangan Pendidikan) and the learning participants' monthly dues. The universal participation referred to the close cooperation between the school planners and the society members around the school in designing, executing, maintaining and developing the strategic plans in order to achieve better school quality.

\section{CONCLUSIONS}

\section{Conclusions}

The concept of quality improvement for the early childhood education has been understood by the caretakers of early child- hood education/kindergarten and has been improveed based on the vision, the missions and the objectives, which include the aspects of planning, process and output. The concept of quality improvement that has been a synergized design will create a good and directed process of developing the early childhood education quality so that the early childhood education generates well-qualified output. The planning of quality improvement programs has been written in the curriculum and the syllabus of each kindergarten and has been implemented in accordance to the standards of development achievement level (STPP, Standar Tingkat Pencapaian Pengembangan). The plan itself includes the annual plan design and the semester plan design and both plans will be elaborated into the weekly activities plan (RKM, Rencana Kegiatan Mingguan) and the daily activities plan (RKH, Rencana Kegiatan Harian). In addition, the school environment has been set in an atmosphere that is full of religious values, manners and slogans that teach habituation and synergy of local wisdom toward all school members.

The approaches, the strategies and the techniques of quality improvement that the early childhood education/kindergarten have selected have been implemented well under the good procedures of planning design by the well-qualified educators and teaching staffs, have been supported by sufficient learning facilities, have been funded by the strong source and have still prioritized the local wisdom in a sense that the approaches, the strategies and the techniques of quality improvement do not abandon the existing cultural values. Furthermore, these approaches, strategies and techniques have been managed by exerting a participatory collaboration that involves all school members, parents and interested parties.

The supporting factors in the development of early childhood education/kindergarten are as follows: (1) the increasing society awareness toward the significance of early childhood education which has been apparent from the increasing number of parents who send their early-age children into the early childhood education although the cost is relatively expensive and the massive socialization effort that the government has pursued by providing training programs for the caretakers and the educators of the early 
childhood education through the Office of Education in order to improve their teaching, parenting and mentoring capacity; and (2) the fact that human resources empowerment has been the main key to improve the quality of early childhood education in addition to the sufficient learning facilities and the supporting learning, parenting and mentoring quality along with the participatory management that has prioritized collectiveness, teamwork, solidarity, cohesiveness and performance quality.

On the other hand, the inhibiting factors in the development of early childhood education/kindergarten are as follows: (1) the lack of parental or societal attention toward the early childhood education and the low society involvement in the early childhood education, especially in the village areas; and (2) the poor-qualified and limited human resources, the limited fund, the lack of facilities and the lack of effective program management.

The standards of achievement level for the educational development within the early childhood education/kindergarten refer to the Minimum Standards of Management (SMM, Standar Manajemen MInimal), the Minimum Standards of Teaching Staffs (SMTK, Standar Minimal Tenaga Kependidikan), the Minimum Standards of Service (SPM, Standar Pelayanan Minimal) and the Minimum Standards of Facilities (SMSP, Standar Minimal Sarana dan Prasarana). According to these standards, the early childhood education/kindergarten have achieved the minimum standards as having been expected. The early childhood education/kindergarten have attained better minimum standards in comparison to the other educational institutions, especially in the aspects of teaching staffs, facilities and management. However, each early childhood educational institution/kindergarten has certain strengths and weaknesses that might be peculiar from one to another.

\section{Suggestions}

Based on the results of the study, the conclusions and the implications, the researcher would like to suggest the following suggestions. First, the socialization on the significance of early childhood education development, especially the kindergarten education in all society layers, should be pursued con- tinuously in order to improve the society participation. Second, attention should be given toward the more optimal development on the educational quality of early childhood education, especially in the kindergarten education, that has been initiated by the goverment, the Educational Foundation, the family or the society. The pre-school age which is known as the golden age, the age where the children experience their intellectual or intelligent development, should be made as the basis for the efforts of developing the future educational quality. Third, there should be techniques and strategies developing the educational quality of early childhood education/kindergarten by designing good plan, preparing well-qualified educators and teaching staffs, providing sufficient facilities, providing sufficient fund, proritizing the local wisdom in a sense that the development should no leave the existing cultural values and implementing participatory management that involves all school members, parents, and interested parties. Fourth, there should development on the professional competencies that the early childhood education/kindergartern teachers possess namely: benefitting the information technology; selecting the appropriate learning type; performing evaluation techniques; conducting scientific studies by training and education programs, workshops and lectures in order to improve the teachers' skills in mentoring and directing the children to develop themselves, to help developing the incapable children,to stimulate the children with APE, to take notes on the children's development and to design lesson plans; and performing appropriate and precise program evaluation. Fifth, inorder to improve the service of early childhood education the learning facilities or the educative tools that meet the standards should be made sufficient gradually so that these facilities and tools might assist the teachers in meeting the targets of children's development. In addition, the government should keep providing technical assistance both in terms of fund and of early childhood education training programs for the caretakers and the teaching staffs in order to improve the educational quality.

\section{REFERENCES}

Anwar, \& Ahmad, A. (2007). Pendidikan anak dini usia: Panduan praktis bagi ibu 
dan calon ibu. Bandung: Alfabeta.

Aqib, Z., Jaiyaroh, S., Diniati, E., \& Khotimah, K. (2009). Penelitian tindakan kelas untuk Guru SD, SLB, dan $T K$. Bandung: CV. Yrama Widya.

Ashiabi, G. S. (2007). Play in the Preschool Classroom: Its Socioemotional Significance and the Teacher's Role in Play. Early Childhood Education Journal, 35(2), 199-207. https://doi.org/10.1007/s10643-0070165-8

Asmani, J. M. (2011). Buku panduan internalisasi pendidikan karakter di sekolah. DIVA Press.

Berk, L. E., \& Meyers, A. B. (2015). Infants, Children, and Adolescents + Myvirtualchild. Pearson College Div.

Carter, D. R., Chard, D. J., \& Pool, J. L. (2009). A family strengths approach to early language and literacy development. Early Childhood Education Journal, 36(6), 519-526. https://doi.org/10.1007/s10643-0090312-5

Crain, W. (2003). Theories of development concepts and applications (4th Editio). New York: Pearson Prentice Hall.

Crosby, P. B. (1979). Quality is free: The art of making quality certain. New York: McGraw-Hill.

Deming, W. E. (1982). Quality productivity and competitive position. Cambridge: Cambridge University Press.

Gardner, H. (2003). Kecerdasan majemuk teori dalam praktek. Batam: Interaksara.

Garvin, D. A. (1988). Managing quality: The strategic and competitive edge. New York: Free Press.

Gordon, A. M., \& Browne, K. W. (2011). Beginnings and beyond: foundations in early childhood education. New York: Wadsworth, Cengage Learning.

Hadis, A., \& Nurhayati. (2010). Psikologi dalam pendidikan. Bandung: Alfabeta.

Haji, N. F. (2004). Konsep manajemen berbasis sekolah (MBS) dan dewan sekolah. Bandung: Pustaka Bani
Quraisy.

Hayat, B., \& Yusuf, S. (2010). Benchmark internasional mutu pendidikan. Jakarta: Bumi Aksara.

Janawi. (2014). Kompetensi guru: citra guru profesional. Bandung: Alfabeta.

Kunandar. (2007). Guru profesional implementasi Kurikulum Tingkat Satuan Pendidikan (KTSP) dan sukses dalam sertifikasi guru. Jakarta: Raja Grafindo Persada.

Mansur, M. (2009). Pendidikan anak usia dini dalam Islam. Yogyakarta: Pustaka Pelajar.

McDevitt, T. M., \& Ormrod, J. E. (2010). Child development and education. Merrill.

Morrison, G. S. (2007). Early childhood education today. New Jersey: Pearson Education Inc.

Nasution, S. (1988). Metode penelitian naturalistik kualitatif. Bandung: Tarsito.

Papalia, D. E., Olds, S. W., Feldman, R. D., \& Gross, D. L. (2001). Human development. McGraw Hill.

Patmonodewo, S. (2003). Pendidikan anak prasekolah. Jakarta: Rineka Cipta.

Presiden Republik Indonesia. Undang-Undang Republik Indonesia nomor 20 tahun 2003 tentang sistem pendidikan nasional, Pub. L. No. 20 (2003). Indonesia.

Putra, N., \& Dwilestari, N. (2012). Penelitian kualitatif PAUD (Pendidikan Anak Usia Dini). Jakarta: Rajawali Pers.

Rakhmat, J. (2003). Psikologi agama: Sebuah pengantar. Jakarta: Mizan Pustaka.

Rushton, C. H. (2010). Ethics of nursing shift report. AACN Advanced Critical Care, 21(4), 380-4. https://doi.org/10.1097/NCI.0b013e3181 ef8648

Sagala, S. (2009). Konsep dan makna pembelajaran untuk membantu memecahkan problematika belajar dan mengajar. Bandung: Alfabeta.

Salkind, N. J. (2004). An introduction to 
theories of human development. Sage Publications.

Sallis, E. (2002). Total quality management in education. Kogan Page.

Santrock, J. (2010). Educational Psychology. Handbook of Educational Psychology. https://doi.org/10.1146/annurev.ps.05.02 0154.002041

Slavin, R. E. (2014). Educational psychology: Theory and practice. Pearson College Div.

Slot, P. L., Leseman, P. P. M., Verhagen, J., \& Mulder, H. (2015). Associations between structural quality aspects and process quality in Dutch early childhood education and care settings. Early Childhood Research Quarterly, 33, 64 76.

https://doi.org/10.1016/j.ecresq.2015.06. 001

Sulistyo, A. (2011). Panduan mengajar dan mendidik anak usia dina. Depok: Milenia Pustaka.

Taylor, S. I., Ogawa, T., \& Wilson, J. (2002). Moral development of Japanese kindergartners. International Journal of Early Childhood, 34(2), 12-18. https://doi.org/10.1007/BF03176763

Taylor, S. J., \& Bogdan, R. (1998). Introduction to qualitative research methods: A guidebook and resource. Wiley.

Uauy, R., \& Dangour, A. D. (2006). Nutrition in brain development and aging: role of essential fatty acids. Nutrition Reviews, 64(5 Pt 2), S24-33-91.

Venetsanou, F., \& Kambas, A. (2010). Environmental factors affecting preschoolers' motor development. Early Childhood Education Journal, 37(4), 319-327. https://doi.org/10.1007/s10643-0090350-z

Werner, E. E., \& Smith, R. S. (2001). Journeys from childhood to midlife; risk, resilience, and recovery. Ithaca, NY: Cornell University Press.

Woolfolk, A. (2007). Educational psychology. New York: Pearson Education, Inc.

Yin, R. K. 1941-. (2014). Case study research : design and methods. Sage Publ.

Yusuf LN., H. S. (2011). Psikologi perkembangan anak dan remaja. Bandung: PT Remaja Rosdakarya. https://doi.org/2006

Zamroni, Z. (2001). Paradigma pendidikan masa depan. Yogyakarta: Bigraf Publishing. 